\title{
Assessment of Heavy Metal Pollution Levels in Sediments and of Ecological Risk by Quality Indices, Applying a Case Study: The Lower Danube River, Romania
}

\author{
Valentina Andreea Calmuc ${ }^{1}$, Madalina Calmuc ${ }^{1}$, Maxim Arseni ${ }^{1}$ (D) Catalina Maria Topa ${ }^{1}$, Mihaela Timofti ${ }^{1}$, \\ Adrian Burada ${ }^{2}$, Catalina Iticescu ${ }^{1, *(1)}$ and Lucian P. Georgescu ${ }^{1}$
}

1 European Center of Excellence for the Environment, Faculty of Sciences and Environment, University of Galati, 800001 Galati, Romania; valentina.calmuc@ugal.ro (V.A.C.); madalina.calmuc@ugal.ro (M.C.); maxim.arseni@ugal.ro (M.A.); catalina.topa@ugal.ro (C.M.T.); mihaela.timofti@ugal.ro (M.T.); lucian.georgescu@ugal.ro (L.P.G.)

2 Danube Delta National Institute for Research and Development, 820112 Tulcea, Romania; adi_burada@yahoo.com

* Correspondence: catalina.iticescu@ugal.ro; Tel.: +40-729-041-801

Citation: Calmuc, V.A.; Calmuc, M.; Arseni, M.; Topa, C.M.; Timofti, M.;

Burada, A.; Iticescu, C.;

Georgescu, L.P. Assessment of Heavy Metal Pollution Levels in Sediments and of Ecological Risk by Quality Indices, Applying a Case Study: The Lower Danube River, Romania. Water 2021, 13, 1801. https://doi.org/ 10.3390/w13131801

Received: 4 June 2021

Accepted: 28 June 2021

Published: 29 June 2021

Publisher's Note: MDPI stays neutral with regard to jurisdictional claims in published maps and institutional affiliations.

Copyright: (c) 2021 by the authors. Licensee MDPI, Basel, Switzerland. This article is an open access article distributed under the terms and conditions of the Creative Commons Attribution (CC BY) license (https:/ / creativecommons.org/licenses/by/ $4.0 /)$.

\begin{abstract}
It is a well-known fact that heavy metal pollution in sediments causes serious problems not only in the Danube basin, but also in the large and small adjacent river streams. A suitable method for assessing the level of heavy metals and their toxicity in sediments is the calculation of pollution indices. The present research aims to assess heavy metal pollution in the Lower Danube surface sediments collected along the Danube course (between 180 and $60 \mathrm{~km}$ ) up to the point where the Danube River flows into the Danube Delta Biosphere Reserve (a United Nations Educational, Scientific and Cultural Organization-UNESCO, protected area). In addition, this monitored area is one of the largest European hydrographic basins. Five heavy metals $(\mathrm{Cd}, \mathrm{Ni}, \mathrm{Zn}, \mathrm{Pb}, \mathrm{Cu})$ were analyzed in two different seasons, i.e., the autumn of 2018 and the spring of 2019, using the Inductively Coupled Plasma Mass Spectrometry (ICP-MS) technique. Our assessment of heavy metal pollution revealed two correlated aspects: 1 . a determination of the potential risks of heavy metals in sediments by calculating the Potential Ecological Risk Index (RI), and 2. an evaluation of the influence of anthropogenic activities on the level of heavy metal contamination in the surface sediments, using three specific pollution indices, namely, the Geo-Accumulation Index (Igeo), the Contamination Factor $(C F)$, and the Pollution Load Index $(P L I)$. The results of this pioneering research activity in the region highlighted the presence of moderate metal $(\mathrm{Ni}$ and $\mathrm{Cd}$ ) pollution and a low potential ecological risk for the aquatic environment.
\end{abstract}

Keywords: lower Danube River; sediment pollution indices; heavy metals; potential ecological risk

\section{Introduction}

The assessment of heavy metal concentration in aquatic ecosystems represents a topic of interest due to heavy metal's toxicity and their special property of bio-accumulation in organisms [1-3]. A total of 23 heavy metals are commonly found in high concentrations in the environment, which can become toxic and dangerous [4], and it is known that population exposure to heavy metals may cause serious medical problems, such as cancer, organ and nervous system damage, autoimmunity, and even death in some instances [5]. The five metals studied in this paper $(\mathrm{Cd}, \mathrm{Ni}, \mathrm{Zn}, \mathrm{Pb}, \mathrm{Cu})$ are the most frequently identified heavy metals in the environment, which, in high concentrations, are considered toxic to ecosystems and human health. For example, studies have shown that human exposure to high levels of $\mathrm{Cd}$ causes kidney disease, infertility, mental, intestinal disorders and cancer [6]. Nickel intoxication determines respiratory dysfunction, heart disorders and cancer [7]. The ingestion of $\mathrm{Zn}$ high levels can cause pancreatic complications, anaemia and 
stomach pain [8]. The most common adverse effects of $\mathrm{Pb}$ in humans are neuronal dysfunction (especially in children), deficits in renal function, hypertension and heart disease, and disorders of the reproductive system [9]. Exposure to high concentrations of $\mathrm{Cu}$ can cause liver, kidney and gastrointestinal disease, damage to the immune system, Wilson's disease and anxiety $[10,11]$. Moreover, contamination of the aquatic environment with these heavy metals can affect aquatic biodiversity, thus causing ecological imbalances [12].

The Danube is a complex aquatic ecosystem, which hosts a large variety of flora and fauna [13], and is likely to be exposed to heavy metal pollution. Since the long biological half-life of heavy metals in the aquatic environment is a major problem at present, recent studies have shown an interest in reducing pollution sources and the toxic action of heavy metals on different types of aquatic life-more precisely, on ichthyofauna, benthic fauna and macrophytes [14]. In addition, several studies have been carried out, highlighting the importance of periodic monitoring of pollutants in aquatic ecosystems using various analysis techniques-in situ (sensor technology) $[15,16]$ or ex situ (spectrometric, chromatographic methods) [17] — to perform a complex environmental assessment.

The main sources of heavy metal pollution along the Lower Danube originate in municipal waste, sewage discharge, pesticides, fertilizers, the burning of fossil fuels and a series of navigation and mining activities [18-21]. Under these circumstances, monitoring of the physico-chemical and biotic qualities of the Danube water should be doubled by an evaluation of the sediments' quality and the development of specific evaluation measures. This means, in our case, evaluating the degree of heavy metal pollution in the Lower Danube water and identifying the appropriate indices which can be used to determine the quality of surface sediments.

As a natural component of the aquatic ecosystem, the sediment serves as a reservoir for a wide variety of pollutants $[22,23]$. Therefore, the excessive presence of heavy metals loads in the sediment from anthropogenic impact can pose a threat to the water supply and produce changes in environmental conditions. This aspect must be taken into account, as the Danube River is the primary water supply for three major cities in south-east Romania, namely, Braila, Galati and Tulcea [24]. In addition, heavy metal contamination in sediments has significant implications for benthic organisms, biota and water quality and numerous invertebrates who process sediments as a food source. Since heavy metals can be bioaccumulated in invertebrate organisms, such metals may subsequently reach the other components of the trophic chain $[25,26]$.

The main aims of this research article are to evaluate and quantify the influence of anthropic activities on the level of heavy metal contamination in the surface sediments of the Lower Danube, and to assess the potential risks to which the aquatic ecosystem is exposed. In order to reach these aims, different specific pollution indices, which are important in assessing the quality of large-stream water bodies, were used and tested, namely the geo-accumulation index (Igeo), contamination factor $(C F)$, Pollution Load Index (PLI) and the Potential Ecological Risk Index (RI). The scientific originality of this paper is represented by the study area, as these quality indices have not been calculated, although there are a wide variety of heavy metal pollution sources nearby. In addition, the investigation area is directly connected to the Danube Delta Biosphere Reserve, which is characterized by rich, UNESCO-protected flora and fauna. For this reason, it is very important to periodically monitor the quality of sediments in this sector.

\section{Materials and Methods}

\subsection{Study Area}

A total of 15 sampling stations were selected to assess the level of heavy metals sediment contamination (Figure 1), according to the existing pollution sources located along the lower Danube River, between 180 and $60 \mathrm{~km}$. In this area, the Danube River crosses three major cities in Romania (Brăila, Galati and Tulcea), with a large number of inhabitants and significant industrial activity (Damen Galati, Navrom Galati, Vard Braila, Vard Tulcea). The monitoring and evaluation of surface sediments quality is important 
because, in this perimeter, the Danube flows into the Danube delta and feeds the largest variety of lakes and canals, hosting a huge variety of fauna and flora unique to Europe.

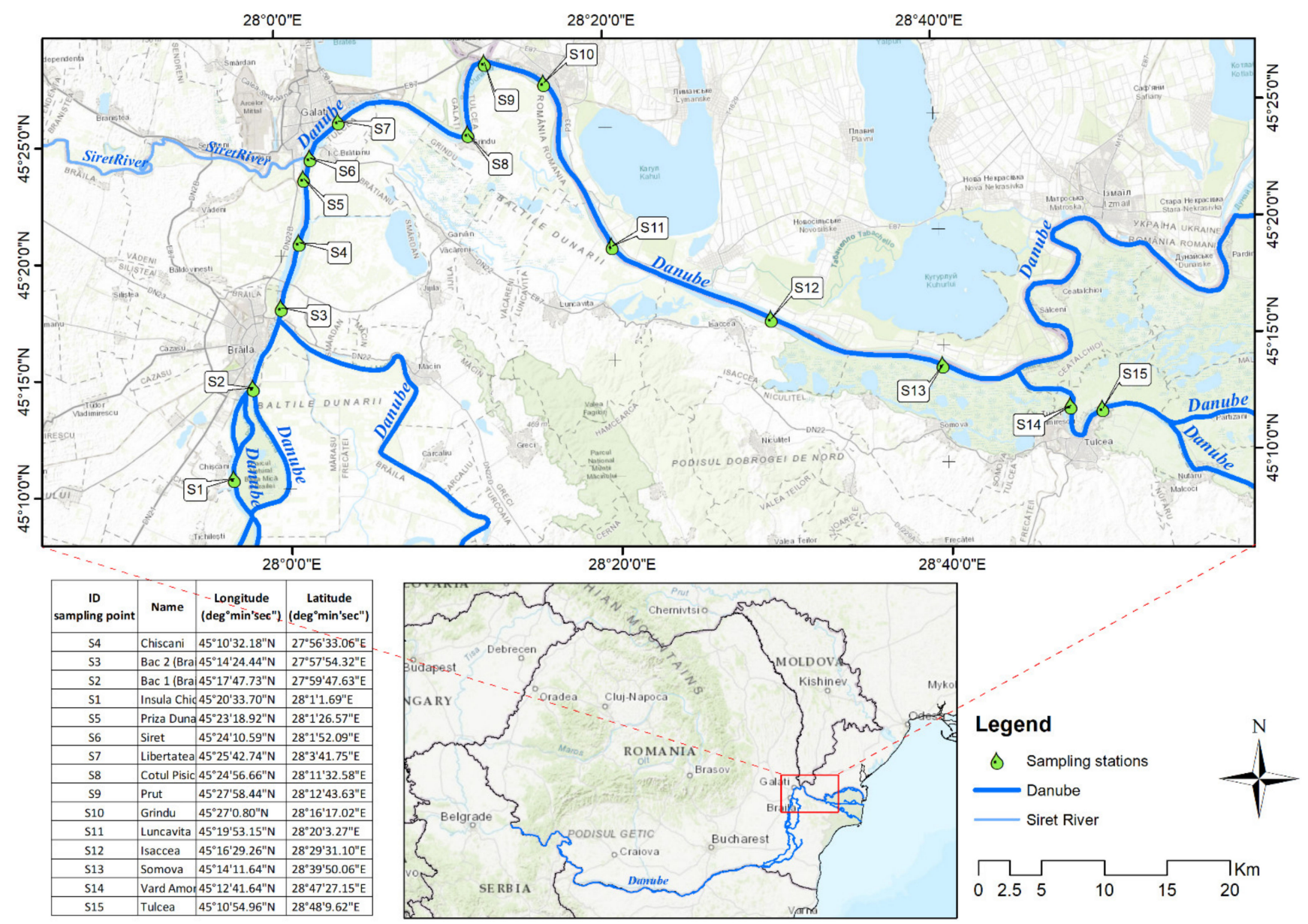

Figure 1. Sampling Stations along the lower Danube River.

Sediment samples were collected monthly over two different seasons, i.e., the autumn of 2018 and the spring of 2019. Considering that there were no significant variations in the heavy metal concentrations in the surface sediments during the three months of a season, the seasonal average was taken into account in the calculation of the pollution indices.

\subsection{Sample Collection and Analysis}

The surface sediment samples were collected using a Van Veen Grab Sampler (KC Denmark A/S, Silkeborg, Denmark) from the first $10 \mathrm{~cm}$ of the sediment surface and deposited in polyethylene recipients. During the transport and temporary storage ( $1 / 2$ days), the sediment samples were preserved at $4{ }^{\circ} \mathrm{C}$. In the preliminary stage, sediment samples were dried at $105^{\circ} \mathrm{C}$ until they reached a constant weight and were sieved using a $125 \mathrm{~mm}$ sieve.

Sediment samples were transported and analyzed in the Chemistry Laboratory of the Danube Delta National Institute for Research and Development, Tulcea, Romania. The mineralization of the samples was performed by the Anton Paar microwave digestion system. After the sample preparation stage, the heavy metal concentrations $(\mathrm{Pb}, \mathrm{Cu}, \mathrm{Cd}$, $\mathrm{Zn}, \mathrm{Ni}$ ) were determined in accordance with the standard SR EN ISO 17294-2, 2005. The analyses were performed using Perkin Elmer ICP-MS Elan DRC-e (PerkinElmer LAS (UK)Ltd, Seer Green, England, UK) [1]. Sediment samples were analyzed in five replicates, for which the relative standard deviations (\%RSDs) were less than $10 \%$ of the trace elements. The calibration curve was made of six points and the calibration standard solutions were 
prepared by successive dilution of a high-purity ICP-multi-element calibration standard (10 $\mu \mathrm{g} / \mathrm{mL}$, batch N9301720, Matrix: 5\% HNO3, PerkinElmer). The methods and results were validated using a Sigma-Aldrich Certified Reference Materials-Metals in soil-batch LRAC3749, PRODUCT ID SQC001. The accuracy of the performed analyses was tested using CRM Metals in soil, batch LRAC3749, PRODUCT ID SQC001 (Merck Romania SRL, Bucharest, Romania, an affiliate of Merck KGaA, Darmstadt, Germany). The percentage ranged between 97 and $114 \%$ for $\mathrm{Pb}$, from 86 to $104 \%$ for $\mathrm{Cu}$, from 87 to $110 \%$ for $\mathrm{Cd}$, from 96 to $114 \%$ for $\mathrm{Zn}$, and from 95 to $108 \%$ for Ni. Table 1 specifies the $\mathrm{R}^{2}$ values obtained for each heavy metal analyzed.

Table 1. $\mathrm{R}^{2}$ values of each heavy metal.

\begin{tabular}{cc}
\hline Element & $\mathbf{R}^{\mathbf{2}}$ \\
\hline $\mathrm{Pb}$ & 0.9997 \\
$\mathrm{Cu}$ & 0.9998 \\
$\mathrm{Cd}$ & 0.9997 \\
$\mathrm{Zn}$ & 0.9999 \\
$\mathrm{Ni}$ & 0.9998 \\
\hline
\end{tabular}

2.3. Methods for Assessing Anthropogenic Contributions to Heavy Metal Sediment Pollution 2.3.1. Calculation of the Geo-Accumulation Index (Igeo)

The Geo-Accumulation Index was proposed by Müller (1969) [27] to assess the pollution levels of each heavy metal in surface sediments, taking their background value into account $[28,29]$. According to Litenithy and Laszlo (1999), Woitke et al. (2003), and Ilie et al. (2017) [30-32], the background values of heavy metals in sediments from the Danube are: $35,0.25,25,10$, and $130 \mathrm{mg} \mathrm{kg}^{-1}$ for $\mathrm{Cu}, \mathrm{Cd}, \mathrm{Pb}, \mathrm{Ni}$ and $\mathrm{Zn}$.

The Igeo was determined using the following equation (Equation (1)) [33-35]:

$$
\text { Igeo }=\log 2 \frac{C n}{K * B n}
$$

where Igeo is the index of geo accumulation for each heavy metal; $\mathrm{Cn}$ is the concentration of heavy metals determined in the sediment sample; $B n$ refers to the background value of heavy metals, $K=1.5$ represents a constant, which compensates for weathering and lithogenic effects [36].

The values of the Igeo allow for an evaluation of the pollution intensity with heavy metals, according to Table 2 .

Table 2. Level of pollution with heavy metals according to Igeo $[37,38]$.

\begin{tabular}{ccc}
\hline Igeo Value & Class & Pollution Intensity \\
\hline Igeo $\leq 0$ & 0 & unpolluted \\
$0<$ Igeo $<1$ & 1 & unpolluted to moderately polluted \\
$1<$ Igeo $<2$ & 2 & moderately polluted \\
$2<$ Igeo $<3$ & 3 & moderately to strongly polluted \\
$3<$ Igeo $<4$ & 4 & strongly polluted \\
$4<$ Igeo $<5$ & 5 & strongly to very strongly polluted \\
Igeo $\geq 5$ & 6 & very strongly polluted \\
\hline
\end{tabular}

\subsubsection{Calculation of the Contamination Factor (CF)}

The contamination factor describes the pollution level of sediment with a given heavy metal and is calculated as the ratio between the concentration of each measured heavy metal $(C n)$ and its background value $\left(C_{b n}\right)$ (Equation (2)) $[39,40]$

$$
C F=\frac{C n}{C_{b n}}
$$


Based on the results obtained for $C F$, the level of heavy metal contamination is established according to Table 3.

Table 3. Contamination level of sediment according to the CF value [41].

\begin{tabular}{cc}
\hline$C F$ Value & Contamination \\
\hline$C F<1$ & Low \\
$1 \leq C F<3$ & Moderate \\
$3 \leq C F<6$ & Considerable \\
$C F>6$ & Very high \\
\hline
\end{tabular}

\subsubsection{Calculation of the Pollution Load Index (PLI)}

The PLI is a tool used to assess the global level of sediment contamination, taking the concentrations of several heavy metals into account. This is calculated based on the CF of each metal (Equation (3)) [42,43]

$$
P L I=\left(C F_{M e 1} \times C F_{M e 2} \times \ldots \times C F_{M e n}\right)^{1 / n}
$$

where $P L I$ is the pollution load index, $C F_{M e 1,2,3, \ldots, n}$ represents the contamination factor of each metal $M e 1,2,3, \ldots, n$ and $n$ is the number of metals.

The values of $P L I<1$ indicate the absence of heavy metal contamination, whereas $P L I>1$ shows the presence of heavy metal pollution $[32,44]$.

\subsection{Method for Assessing the Potential Risks of Heavy Metals}

Calculation of Potential Ecological Risk Index $(R I)$

The $R I$ was calculated to assess the potential risks from heavy metals from surface sediments. This index was developed by Hakänson (1980) [45] to evaluate the potential risk of heavy metal contamination in sediments. This method takes the toxicity and combined effects of heavy metals on the aquatic ecosystem into account [46]. According to Hakänson (1980) the toxic response factors for the analyzed heavy metals, such as $\mathrm{Pb}, \mathrm{Cu}, \mathrm{Cd}, \mathrm{Zn}$ and $\mathrm{Ni}$, are 5, 5, 30,1 and 5. The final value of $R I$ is obtained by calculating the following formulas [47-53]

$$
\begin{gathered}
R I=\sum E r^{M e} \\
E r^{M e}=T r^{M e} \times C F^{M e} \\
C F^{M e}=\frac{C^{M e}}{C_{S C M}^{M e}}
\end{gathered}
$$

where RI (Table 4 lists the levels of ecological risk according to the obtained $R I$ index value) is the sum of potential risk of individual heavy metal; $E r^{M e}$ is the potential ecological risk of individual metal Me; $T r^{M e}$ refers to the toxic-response factor for each metal Me; $C F^{M e}$ is the contamination factor for each metal Me; $C^{M e}$ is the measured level of heavy metal in the sediment; $C_{S C M}{ }^{M e}$ is the standard value of each heavy metal concentration according to the Romanian Order 161/2006 (Table 5).

Table 4. Values of the RI [54].

\begin{tabular}{ccc}
\hline Er $^{\mathrm{Me}}$ Value & RI Value & Ecological Risk Level \\
\hline$E r^{M e} \leq 40$ & $R I<150$ & Low \\
$40<E r^{M e} \leq 80$ & $150 \leq R I<300$ & Moderate \\
$80<E r^{M e} \leq 160$ & $300 \leq R I<600$ & Considerable \\
$160<E r^{M e} \leq 320$ & & High \\
$E r^{M e}>320$ & $R I \geq 600$ & Very high \\
\hline
\end{tabular}


Table 5. Standard value of each heavy metal concentration in the sediment according to the Romanian Order 161/2006 [47].

\begin{tabular}{cc}
\hline Heavy Metal & Standard Value $\left.\mathbf{( m g} \cdot \mathbf{k g} \mathbf{~}^{\mathbf{1}}\right)$ \\
\hline $\mathrm{Cd}$ & 0.8 \\
$\mathrm{Cu}$ & 40 \\
$\mathrm{~Pb}$ & 85 \\
$\mathrm{Zn}$ & 150 \\
$\mathrm{Ni}$ & 35 \\
\hline
\end{tabular}

Table 6 shows the average values of heavy metal concentrations and standard deviations, obtained during the two seasons studied (autumn of 2018 and spring of 2019), in the 15 monitoring stations. Based on these results, the indices presented above were calculated. The obtained results indicate that the concentrations of the five metals measured in the Danube surface sediments are increasing in the sequence of $\mathrm{Cd}<\mathrm{Pb}<\mathrm{Cu}<\mathrm{Ni}<\mathrm{Zn}$.

In order to assess the spatial distribution of the heavy metal contamination level in the surface sediments, the values obtained for the Igeo, the PLI and the RI were represented in the form of pollution maps (Figures 2, 3 and 5). 
Table 6. Seasonal average of heavy metal concentrations and standard deviation.

\begin{tabular}{|c|c|c|c|c|c|c|c|c|c|c|c|c|c|c|c|c|c|c|}
\hline & & & & S1 & S2 & S3 & S4 & S5 & S6 & S7 & S8 & S9 & S10 & S11 & S12 & S13 & S14 & S15 \\
\hline \multirow{20}{*}{ 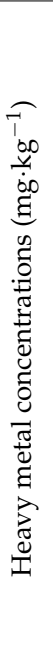 } & \multirow{4}{*}{$\mathrm{Pb}$} & \multirow{2}{*}{ Autumn } & Mean & 5.90 & 8.96 & 12.57 & 8.49 & 7.93 & 5.17 & 7.28 & 21.14 & 4.84 & 7.55 & 7.83 & 6.84 & 8.29 & 8.11 & 5.34 \\
\hline & & & Std.dev & 0.15 & 0.64 & 0.82 & 0.56 & 0.26 & 0.21 & 0.45 & 1.60 & 0.48 & 0.12 & 0.42 & 0.52 & 0.57 & 0.63 & 0.38 \\
\hline & & \multirow{2}{*}{ Spring } & Mean & 6.02 & 6.05 & 13.78 & 6.41 & 5.70 & 4.17 & 5.68 & 10.35 & 4.31 & 8.33 & 14.64 & 9.87 & 9.90 & 6.76 & 8.01 \\
\hline & & & Std.dev & 0.44 & 0.23 & 0.55 & 0.18 & 0.43 & 0.28 & 0.32 & 0.63 & 0.27 & 0.50 & 0.22 & 0.39 & 0.61 & 0.59 & 0.52 \\
\hline & \multirow{4}{*}{$\mathrm{Cu}$} & \multirow[b]{2}{*}{ Autumn } & Mean & 4.30 & 10.72 & 17.39 & 12.58 & 12.54 & 7.60 & 11.81 & 10.24 & 7.89 & 13.42 & 6.68 & 9.79 & 16.64 & 15.17 & 9.42 \\
\hline & & & Std.dev & 0.11 & 0.87 & 0.72 & 0.39 & 0.68 & 0.46 & 0.34 & 0.49 & 0.25 & 1.06 & 0.38 & 0.44 & 0.53 & 0.49 & 0.27 \\
\hline & & \multirow{2}{*}{ Spring } & Mean & 10.31 & 11.65 & 25.01 & 8.97 & 10.08 & 7.55 & 7.47 & 19.47 & 9.29 & 17.18 & 27.50 & 20.75 & 23.29 & 9.29 & 10.07 \\
\hline & & & Std.dev & 0.80 & 0.41 & 0.49 & 0.40 & 0.64 & 0.44 & 0.72 & 0.28 & 0.33 & 1.11 & 0.88 & 0.39 & 0.68 & 0.48 & 0.66 \\
\hline & \multirow{4}{*}{$\mathrm{Cd}$} & \multirow[b]{2}{*}{ Autumn } & Mean & 0.30 & 0.59 & 0.74 & 0.50 & 0.50 & 0.46 & 0.57 & 0.54 & 0.54 & 0.76 & 0.53 & 0.63 & 0.75 & 0.57 & 0.53 \\
\hline & & & Std.dev & 0.006 & 0.025 & 0.053 & 0.016 & 0.044 & 0.012 & 0.028 & 0.036 & 0.015 & 0.023 & 0.044 & 0.028 & 0.034 & 0.016 & 0.019 \\
\hline & & \multirow{2}{*}{ Spring } & Mean & 0.59 & 0.65 & 0.99 & 0.63 & 0.57 & 0.41 & 0.46 & 0.78 & 0.46 & 0.65 & 0.72 & 0.77 & 0.82 & 0.48 & 0.52 \\
\hline & & & Std.dev & 0.027 & 0.015 & 0.032 & 0.04 & 0.043 & 0.036 & 0.019 & 0.029 & 0.035 & 0.041 & 0.043 & 0.036 & 0.033 & 0.027 & 0.038 \\
\hline & \multirow{4}{*}{$\mathrm{Zn}$} & \multirow[b]{2}{*}{ Autumn } & Mean & 58.84 & 118.54 & 120.76 & 87.43 & 84.15 & 62.39 & 84.65 & 77.64 & 64.48 & 146.23 & 85.40 & 96.11 & 121.38 & 117.01 & 69.97 \\
\hline & & & Std.dev & 1.34 & 1.27 & 1.32 & 0.98 & 1.46 & 1.55 & 1.68 & 1.32 & 1.08 & 1.56 & 0.98 & 1.44 & 1.39 & 1.70 & 1.03 \\
\hline & & \multirow{2}{*}{ Spring } & Mean & 78.69 & 84.21 & 177.33 & 73.57 & 95.67 & 71.27 & 63.21 & 131.50 & 66.06 & 121.05 & 161.24 & 146.53 & 154.34 & 81.26 & 86.43 \\
\hline & & & Std.dev & 0.78 & 1.22 & 0.96 & 0.87 & 1.33 & 1.62 & 1.39 & 0.85 & 0.52 & 1.31 & 0.99 & 1.63 & 1.28 & 1.75 & 1.08 \\
\hline & \multirow{4}{*}{$\mathrm{Ni}$} & \multirow{2}{*}{ Autumn } & Mean & 16.03 & 29.12 & 27.88 & 22.31 & 20.53 & 14.00 & 19.99 & 22.09 & 16.28 & 23.90 & 24.83 & 24.76 & 28.35 & 38.81 & 16.94 \\
\hline & & & Std.dev & 0.96 & 1.69 & 0.98 & 1.77 & 1.32 & 1.24 & 0.96 & 1.08 & 1.37 & 1.54 & 1.80 & 1.30 & 1.96 & 1.33 & 1.04 \\
\hline & & \multirow{2}{*}{ Spring } & Mean & 20.17 & 19.33 & 35.80 & 16.04 & 24.58 & 19.09 & 17.65 & 28.49 & 17.40 & 27.41 & 50.46 & 32.55 & 39.03 & 25.85 & 28.13 \\
\hline & & & Std.dev & 0.85 & 0.98 & 1.32 & 0.96 & 0.58 & 1.36 & 1.26 & 1.44 & 1.28 & 1.63 & 1.82 & 0.96 & 1.22 & 1.14 & 0.85 \\
\hline
\end{tabular}




\section{Results and Discussion}

\subsection{Spatial Distribution of Geo-Accumulation Index (Igeo)}

Based on the Igeo values obtained in autumn 2018, a moderate to strong cadmium pollution can be observed in stations: S3, S10 and S13 (Figure 2). Usually, industry, and the combustion of fossil fuels and agriculture (phosphoric fertilizers) represent the main sources of environmental pollution with cadmium [4,55-57]. During spring, the highest values of Igeo Cd $(2<$ Igeo $<3)$ were recorded in stations S3, S8, S11, S12, S13. These monitoring stations are located near the ferry crossing (S3) and the agricultural lands (S8, $\mathrm{S} 11, \mathrm{~S} 12, \mathrm{~S} 13)$.

The Igeo values for Ni ranged between 1.07 (S6) and 2.54 (S14) during the autumn of 2018 and 1.27 (S4)-2.92 (S11) during spring, 2019. According to Igeo, the pollution of $\mathrm{Ni}$ varies from Class 2 (moderately polluted) to Class 3 (moderately to strongly polluted). For this metal, limit allowed according by the Romanian Order 161/2006 $\left(35 \mathrm{mg} \mathrm{kg}^{-1}\right)$ was exceeded in stations S3, S11, S13, S14 (Table 5). Similar results regarding the level of pollution with Ni were reported in the research of Ilie et al. (2017) along the Danube [32]. Across the monitored Lower Danube sector, the presence and persistence of nickel pollution can have several causes, such as transport, industry, municipal and industrial waste [58].

The Igeo values of $\mathrm{Pb}(-1.78-0.34$ during autumn and $-2.00-1.03$ during spring) indicate the level of unpolluted sediment in most of the sampling stations, except for station S8, where the sediment was classified as "unpolluted to moderately polluted" in the autumn of 2018. Additionally, the result of the Igeo calculation for autumn season shows that $\mathrm{Cu}$ values for all sites were within the uncontaminated class (Igeo $\leq 0)$. On the other hand, two of the 15 stations (S3,S11) were unpolluted to moderately polluted with $\mathrm{Cu}$ in the spring season. Regarding the $\mathrm{Zn}$ metal, the Igeo values ranged from -0.56 (S1) to 0.75 (S10) (during the autumn of 2018) and -0.46 (S7)-1.03 (S3) (during the spring of 2019). The highest value of this index was obtained for station $S 3\left(177.33 \mathrm{mg} \mathrm{kg}^{-1}\right)$ where an exceedance of the allowed limit for $\mathrm{Zn}\left(150 \mathrm{mg} \mathrm{kg}^{-1}\right)$ was registered. The majority of results obtained for this metal indicate the unpolluted to moderately polluted status of the sediment in both monitored periods.
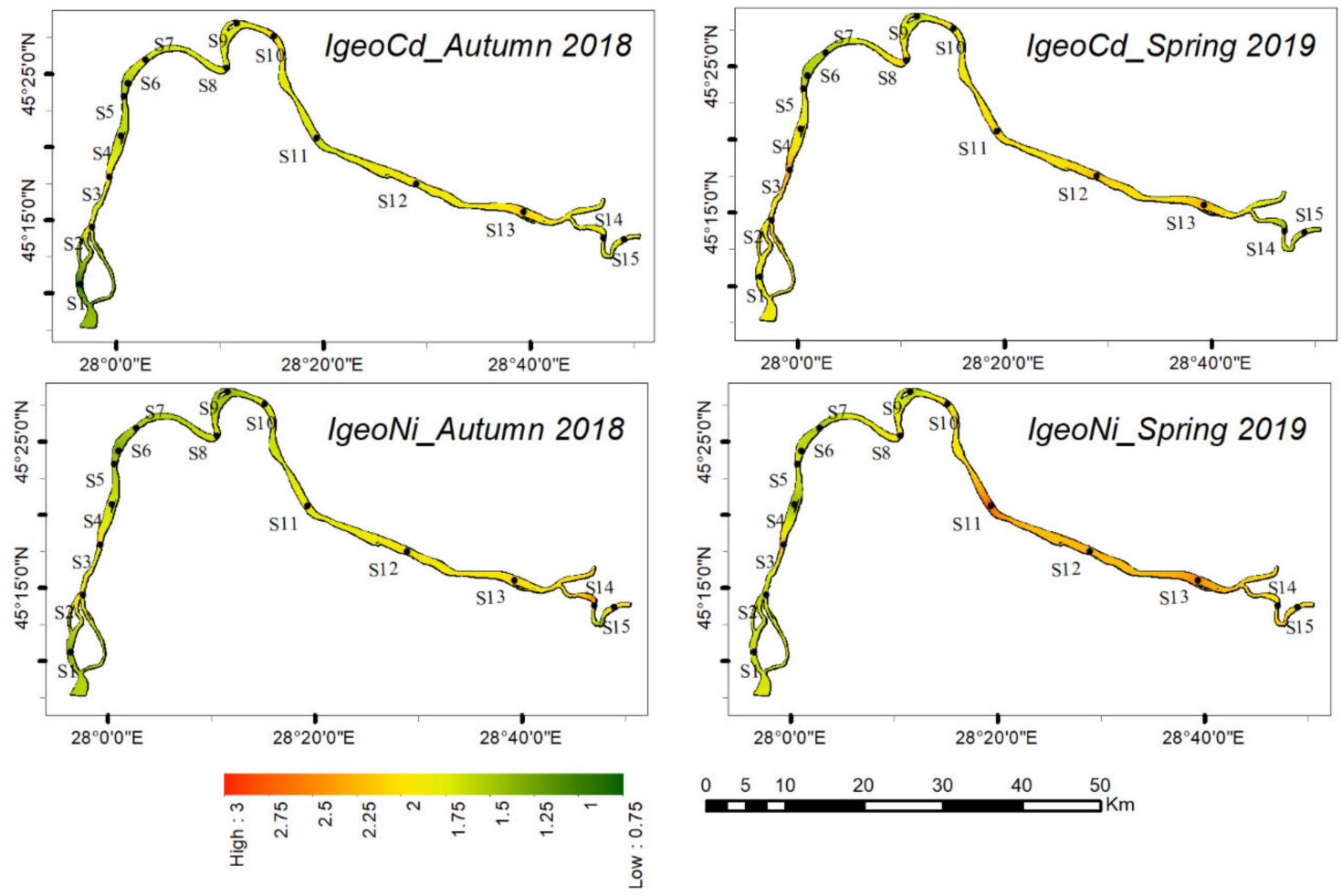

Figure 2. Cont. 

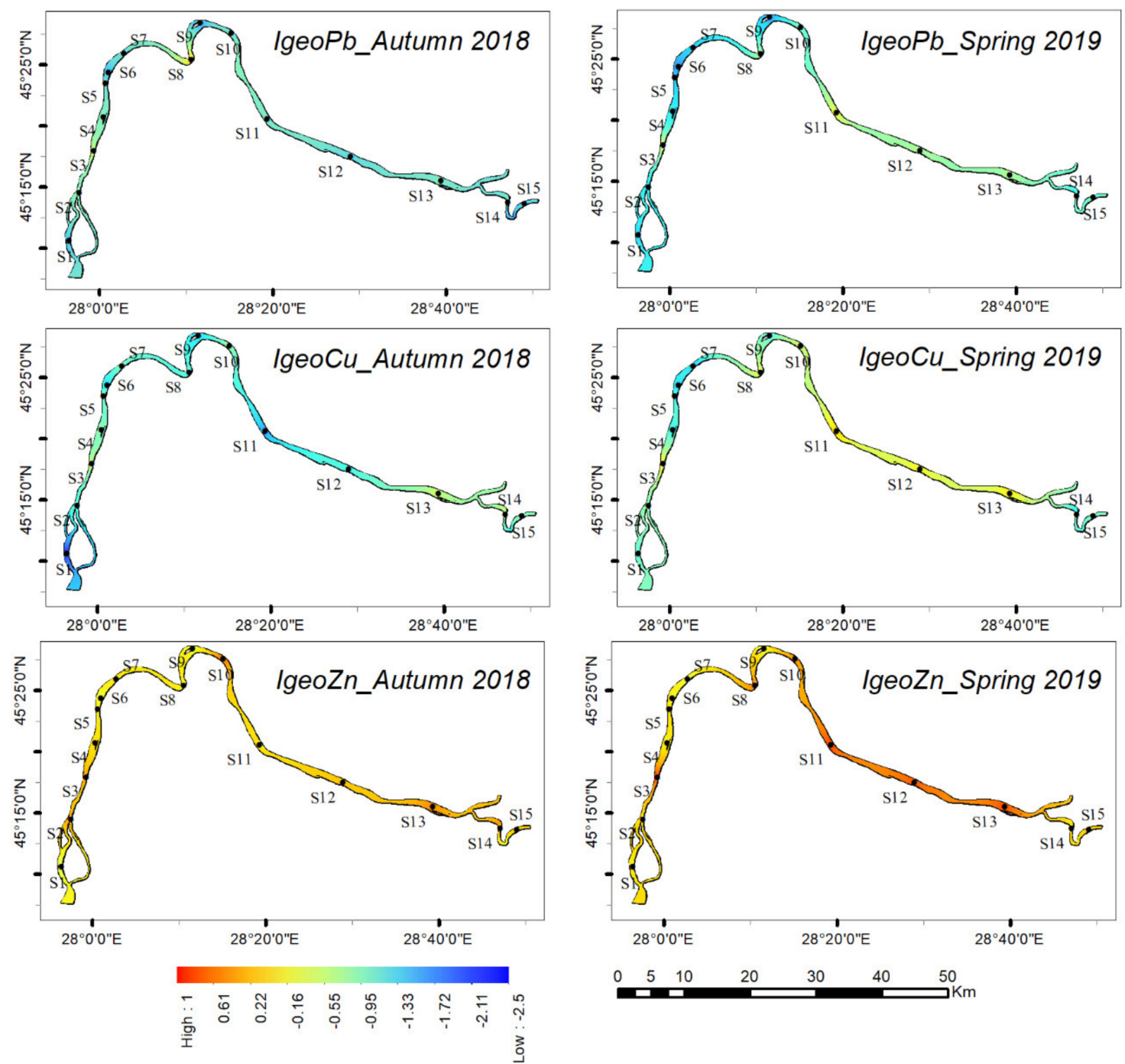

Figure 2. Spatial distribution of the Igeo for Cd, Ni, Pb, Cu and $\mathrm{Zn}$ in the autumn of 2018 and the spring of 2019.

\subsection{Contamination Factor (CF) and Pollution Load Index (PLI)}

The CF calculation indicates results similar to the Igeo values, but the difference between these two indices is that Igeo is used to reflect the degree of sediment contamination of each metal, taking the lithogenic effects, natural fluctuations in metals and some small anthropogenic influences into account [53]. On the other hand, CF is a precursor to calculating the PLI index, representing an integral part of the formula of this index. In our analysis, the results of the CF of each metal show a low contamination of sediments with heavy metals such as $\mathrm{Pb}$ and $\mathrm{Cu}$ in all the sampling sites, in both monitored seasons $(C F<1)$. For Zn metal, CF values (Table 7) indicate low contamination in most monitored stations, with the exception of stations S3, S8, S11-S13, which show moderate contamination $(1 \leq C F<3)$ during the spring season. In agreement with the $C F$ index, during the autumn season, all 15 sites were moderately contaminated with $\mathrm{Cd}$, while, during the spring season, only 11 stations reported moderate contamination; the rest (S3, S8, S12, S13) recorded considerable contamination. The highest value of the $C F$ was recorded for Ni during the spring season, in monitoring station S11 (5.05). The level of sediment pollution with Ni was moderate in most sites, with the exception of stations S14 (autumn of 2018), S3, and S11-S13 (spring of 2019), where considerable contamination was measured. 
Table 7. $C F$ values.

\begin{tabular}{|c|c|c|c|c|c|c|c|c|c|c|}
\hline \multirow{3}{*}{ Sites } & \multicolumn{10}{|c|}{ Metals } \\
\hline & \multicolumn{2}{|c|}{$\mathbf{P b}$} & \multicolumn{2}{|c|}{$\mathrm{Cu}$} & \multicolumn{2}{|c|}{$\mathrm{Cd}$} & \multicolumn{2}{|c|}{$\mathrm{Zn}$} & \multicolumn{2}{|c|}{$\mathrm{Ni}$} \\
\hline & Autumn & Spring & Autumn & Spring & Autumn & Spring & Autumn & Spring & Autumn & Spring \\
\hline S1 & 0.24 & 0.24 & 0.12 & 0.29 & 1.22 & 2.36 & 0.45 & 0.61 & 1.60 & 2.02 \\
\hline $\mathrm{S} 2$ & 0.36 & 0.24 & 0.31 & 0.33 & 2.37 & 2.58 & 0.91 & 0.65 & 2.91 & 1.93 \\
\hline S3 & 0.50 & 0.55 & 0.50 & 0.71 & 2.96 & 3.96 & 0.93 & 1.36 & 2.79 & 3.58 \\
\hline S4 & 0.34 & 0.26 & 0.36 & 0.26 & 1.99 & 2.50 & 0.67 & 0.57 & 2.23 & 1.60 \\
\hline S5 & 0.32 & 0.23 & 0.36 & 0.29 & 2.00 & 2.26 & 0.65 & 0.74 & 2.05 & 2.46 \\
\hline S6 & 0.21 & 0.17 & 0.22 & 0.22 & 1.84 & 1.65 & 0.48 & 0.55 & 1.40 & 1.91 \\
\hline S7 & 0.29 & 0.23 & 0.34 & 0.21 & 2.29 & 1.83 & 0.65 & 0.49 & 2.00 & 1.77 \\
\hline S8 & 0.85 & 0.41 & 0.29 & 0.56 & 2.18 & 3.12 & 0.60 & 1.01 & 2.21 & 2.85 \\
\hline S9 & 0.19 & 0.17 & 0.23 & 0.27 & 2.15 & 1.83 & 0.50 & 0.51 & 1.63 & 1.74 \\
\hline $\mathrm{S} 10$ & 0.30 & 0.33 & 0.38 & 0.49 & 3.02 & 2.59 & 1.12 & 0.93 & 2.39 & 2.74 \\
\hline $\mathrm{S} 11$ & 0.31 & 0.59 & 0.19 & 0.79 & 2.11 & 2.87 & 0.66 & 1.24 & 2.48 & 5.05 \\
\hline $\mathrm{S} 12$ & 0.27 & 0.39 & 0.28 & 0.59 & 2.52 & 3.09 & 0.74 & 1.13 & 2.48 & 3.26 \\
\hline $\mathrm{S} 13$ & 0.33 & 0.40 & 0.48 & 0.67 & 2.99 & 3.29 & 0.93 & 1.19 & 2.84 & 3.90 \\
\hline S14 & 0.32 & 0.27 & 0.43 & 0.27 & 2.30 & 1.90 & 0.90 & 0.63 & 3.88 & 2.59 \\
\hline $\mathrm{S} 15$ & 0.21 & 0.32 & 0.27 & 0.29 & 2.13 & 2.08 & 0.54 & 0.66 & 1.69 & 2.81 \\
\hline
\end{tabular}

Analyzing the spatial distribution of the PLI related to the two monitored seasons (the autumn of 2018 and the spring of 2019), it can be observed that the PLI values ranged from 0.53 (S1) to 1.17 (S3) in the autumn months, which indicates the absence of heavy metal pollution $(P L I<1)$ in $73 \%$ of the monitored stations. During spring 2019, Figure 3 illustrates that $P L I$ values ranged from 0.57 (S6) to 1.53 (S11), indicating the presence of sediments heavy metal pollution, especially in monitoring stations S11-S13 (PLI > 1).
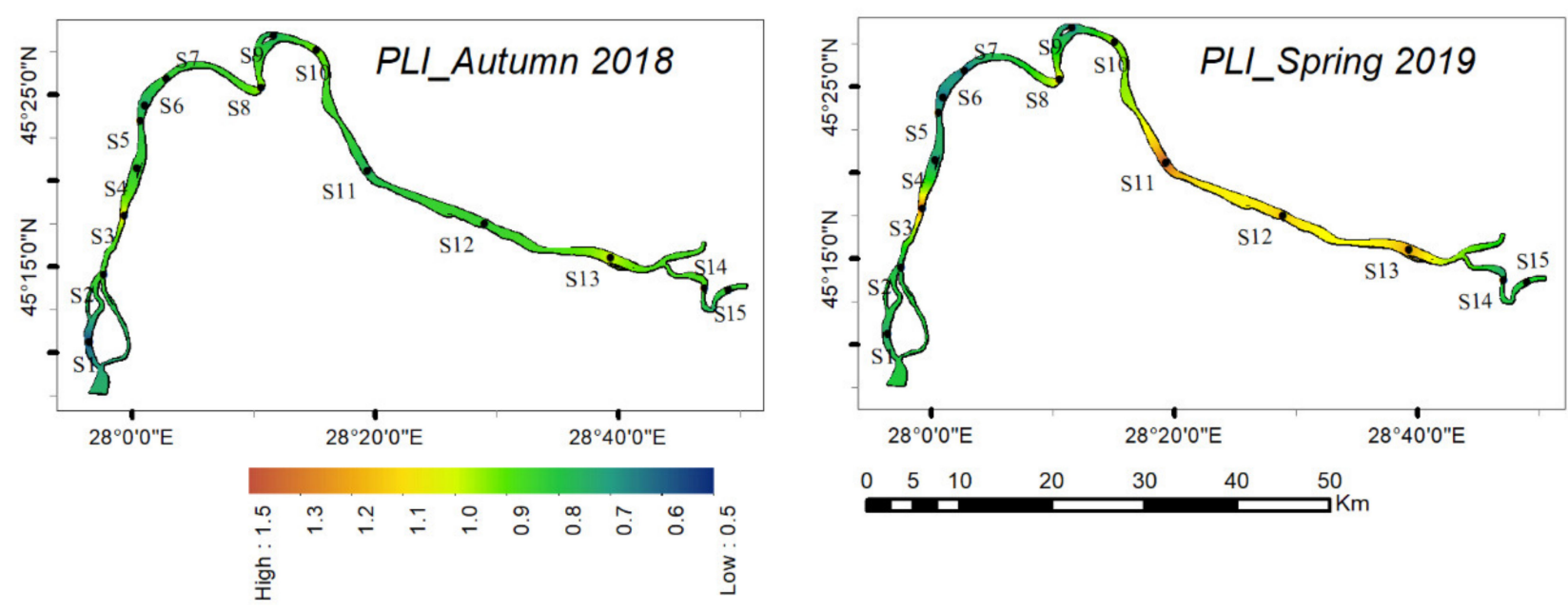

Figure 3. Spatial distribution of the PLI in the autumn of 2018 and the spring of 2019.

The present study highlights the differences in heavy metal concentrations measured in surface sediments between the monitoring stations and the two seasons. In order to highlight the difference between the two seasons, Principal Component Analysis (PCA) was applied (Figure 4). Figure 4 displays a significantly different distribution between the two seasons of the obtained values, especially for the metals $\mathrm{Cd}, \mathrm{Cu}, \mathrm{Ni}$ and $\mathrm{Zn}$. In contrast, there were no important seasonal variations in $\mathrm{Pb}$ concentrations. Moreover, from the PCA statistical analysis, it was observed that, for the heavy metals $\mathrm{Cu}, \mathrm{Ni}, \mathrm{Zn}$ and $\mathrm{Cd}$, higher concentrations were registered during the spring season for most sediment samples. 


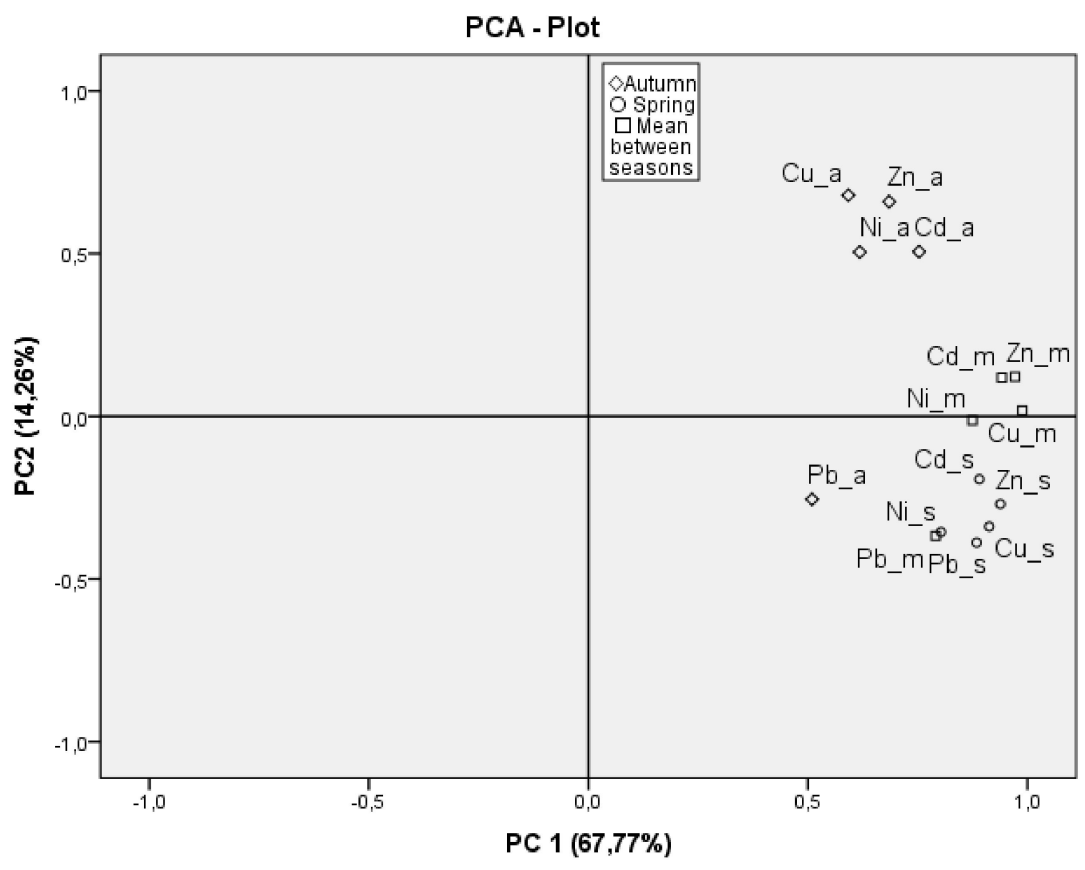

Figure 4. The PCA plot of seasonal variations in heavy metal concentrations.

Following the analysis of the seasonal average flows (Table 8), it can be observed that the pollution increases when the average discharge flows are maximum, i.e., in the spring season, when the average flow at the four hydrometric stations reached $5796 \mathrm{~m}^{3} \mathrm{~s}^{-1}$. With the increase in the discharge, the water velocity also increases; thus, the sediment transport becomes more active. The highwater velocities and high discharge cause the sediments to be transported from upstream to downstream and deposited in the areas where the Danube section has lower flow slopes. Therefore, high concentration values can be observed in sampling points S11-S13, where the flow slope decreases significantly.

Table 8. Danube River mean discharge flows $\left(Q_{m}\right)$ during autumn of 2018 and spring of 2019.

\begin{tabular}{ccc}
\hline \multirow{2}{*}{ Hydrometric Stations } & \multicolumn{2}{c}{$\left.\mathbf{Q}_{\mathbf{m}} \mathbf{~ ( m}^{\mathbf{3}} \mathbf{s}^{-\mathbf{1}}\right)$} \\
\cline { 2 - 3 } & Autumn of 2018 & Spring of 2019 \\
\hline Brăila (km 170) & 3220 & 6263 \\
Galați (km 150) & 3677 & 6803 \\
Isaccea (km 103) & 3127 & 6673 \\
Tulcea (km 71) & 1627 & 3443 \\
Average flow & 2913 & 5796 \\
\hline
\end{tabular}

Another explanation can be given by the fact that, in the area of points S1-S10, the river sector has a very sinuous path. Therefore, the sedimentation takes place much further downstream, i.e., in the area of points S11-S13, where the course becomes linear, and the width of the riverbed increases. With the increase in the river width, there is a decrease in the flow velocities as well as the depths specific to this area. This favors the deposition of sediments in these places, especially those with high concentrations of heavy metals $[59,60]$.

\subsection{Spatial Distribution of Potential Ecological Risk Index (RI)}

The $R I$ index was calculated based on the five heavy metals $(\mathrm{Pb}, \mathrm{Zn}, \mathrm{Cd}, \mathrm{Cu}$ and $\mathrm{Ni})$, and the results comprehensively reflect a low ecological risk level for each single element $\left(E r^{M e} \leq 40\right)($ Table 9), as well as a low degree of general ecological risk for both monitored seasons (Figure 5). In addition, RI results in the surface sediment ranged from 15.00 (S1) to 35.50 (S13) during the autumn season and 17.61 (S6) to 45.96 (S3) during the spring season. 
Table 9. Potential ecological risk of individual metal $\left(E r^{M e}\right)$ values.

\begin{tabular}{|c|c|c|c|c|c|c|c|c|c|c|}
\hline \multirow{3}{*}{ Sites } & \multicolumn{10}{|c|}{ Metals } \\
\hline & \multicolumn{2}{|c|}{$\mathbf{P b}$} & \multicolumn{2}{|c|}{$\mathrm{Cu}$} & \multicolumn{2}{|c|}{$\mathrm{Cd}$} & \multicolumn{2}{|c|}{$\mathrm{Zn}$} & \multicolumn{2}{|c|}{$\mathrm{Ni}$} \\
\hline & Autumn & Spring & Autumn & Spring & Autumn & Spring & Autumn & Spring & Autumn & Spring \\
\hline S1 & 0.35 & 0.35 & 0.54 & 1.29 & 11.43 & 22.11 & 0.39 & 0.52 & 2.29 & 2.88 \\
\hline $\mathrm{S} 2$ & 0.53 & 0.36 & 1.34 & 1.46 & 22.19 & 24.21 & 0.79 & 0.56 & 4.16 & 2.76 \\
\hline S3 & 0.74 & 0.81 & 2.17 & 3.13 & 27.75 & 37.15 & 0.81 & 1.18 & 3.98 & 5.11 \\
\hline S4 & 0.50 & 0.38 & 1.57 & 1.12 & 18.65 & 23.44 & 0.58 & 0.49 & 3.19 & 2.29 \\
\hline S5 & 0.47 & 0.34 & 1.57 & 1.26 & 18.76 & 21.20 & 0.56 & 0.64 & 2.93 & 3.51 \\
\hline S6 & 0.30 & 0.25 & 0.95 & 0.94 & 17.28 & 15.49 & 0.42 & 0.48 & 2.00 & 2.73 \\
\hline S7 & 0.43 & 0.33 & 1.48 & 0.93 & 21.49 & 17.13 & 0.56 & 0.42 & 2.86 & 2.52 \\
\hline S8 & 1.24 & 0.61 & 1.28 & 2.43 & 20.42 & 29.23 & 0.52 & 0.88 & 3.16 & 4.07 \\
\hline S9 & 0.28 & 0.25 & 0.99 & 1.16 & 20.14 & 17.19 & 0.43 & 0.44 & 2.33 & 2.49 \\
\hline $\mathrm{S} 10$ & 0.44 & 0.49 & 1.68 & 2.15 & 28.33 & 24.24 & 0.97 & 0.81 & 3.41 & 3.92 \\
\hline $\mathrm{S} 11$ & 0.46 & 0.86 & 0.84 & 3.44 & 19.80 & 26.91 & 0.57 & 1.07 & 3.55 & 7.21 \\
\hline $\mathrm{S} 12$ & 0.40 & 0.58 & 1.22 & 2.59 & 23.62 & 28.92 & 0.64 & 0.98 & 3.54 & 4.65 \\
\hline $\mathrm{S} 13$ & 0.49 & 0.58 & 2.08 & 2.91 & 28.07 & 30.86 & 0.81 & 1.03 & 4.05 & 5.58 \\
\hline S14 & 0.48 & 0.40 & 1.90 & 1.16 & 21.55 & 17.84 & 0.78 & 0.54 & 5.54 & 3.69 \\
\hline S15 & 0.31 & 0.47 & 1.18 & 1.26 & 19.99 & 19.45 & 0.47 & 0.58 & 2.42 & 4.02 \\
\hline
\end{tabular}
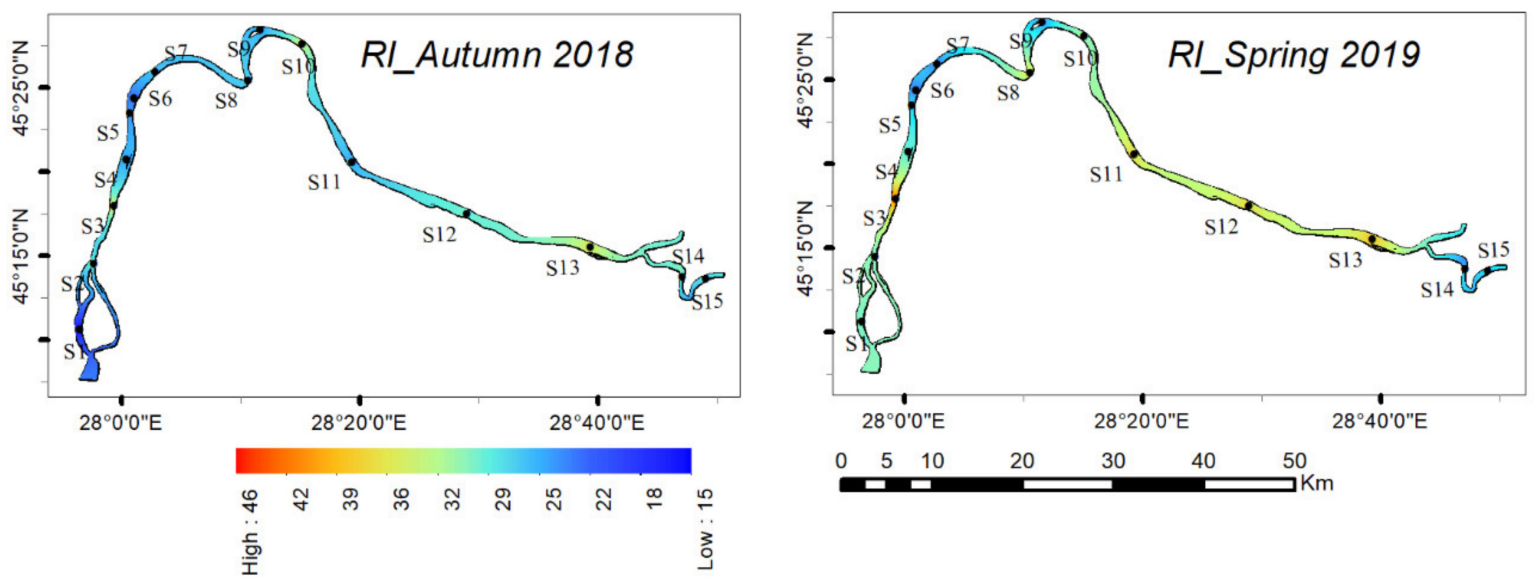

Figure 5. Spatial distribution of the $R I$ in the autumn of 2018 and the spring of 2019.

The $E r^{M e}$ results of heavy metals in the surface sediments of the Lower Danube are shown in Table 9. The most significant values of Er were recorded for Cd, because, according to Hakanson's approach, the toxic response of this metal is the highest. However, it does not represent a high ecological risk in the Lower Danube sediments, due to the fact that the measured $\mathrm{Cd}$ values are situated below the permitted limit according to the Romanian Order 161/2006. The second metal that made an important contribution to the final result of the RI index is Ni. Similar to the PLI index, the highest $R I$ values were recorded during the spring season for stations S3 and S11-S13 (Figure 5).

\section{Conclusions}

In this study, the indices Igeo, CF, PLI and RI were calculated to determine the degree of heavy metal pollution of lower Danube surface sediments and their potential ecological risk.

The results of the Igeo, CF and the PLI indicated that a heavy metal load with $\mathrm{Ni}$ and $\mathrm{Cd}$ in surface sediments is due to anthropogenic activities, and had an influence on the pollution levels of the lower Danube surface sediments analysed. Generally, Igeo and CF suggested that the average concentrations of heavy metals analyzed in the sediment were 
higher than the background value. However, in most sites, no significant pollution was identified for the heavy metals $\mathrm{Pb}$ and $\mathrm{Cu}$.

According to the potential ecological risk of individual metal $\left(E r^{M e}\right)$, the values of the $R I$ index were influenced by the heavy metals in the following sequence: $\mathrm{Pb}<\mathrm{Zn}<\mathrm{Cu}$ $<\mathrm{Ni}<\mathrm{Cd}$. However, the RI values revealed the existence of a low ecological risk for the surface sediments, as the limits for most heavy metals were not significantly exceeded.

In addition, the results of the pollution indices tested in the present study indicate the existence of temporal and spatial fluctuations regarding the pollution level with certain heavy metals, due to the presence of pollution sources, heavy metal mobility, sediment characteristics, sediment transport, the hydro-morphological profile of the river and climatic conditions [61].

In the future, these indices may be included together with other water quality indices (i.e., WQI) in a global index, to perform a complex assessment of the Danube River quality.

Author Contributions: Conceptualization, V.A.C. and C.I.; Data curation, M.C. and M.A.; Formal analysis, M.C., M.T. and M.A.; Funding acquisition, C.I. and L.P.G.; Investigation, V.A.C., C.M.T. and L.P.G.; Methodology, V.A.C., A.B., C.I. and L.P.G.; Writing-original draft preparation, V.A.C., C.M.T. and C.I. All authors have read and agreed to the published version of the manuscript.

Funding: This research was funded by the Romanian Ministry of Research and Innovation, by the project DANS, 4/2018.

Institutional Review Board Statement: Not applicable.

Informed Consent Statement: Not applicable.

Data Availability Statement: Not applicable.

Acknowledgments: The linguistic review of the present article was made by Antoanela Marta Madar, member of the Research Center "Interface Research of the Original and Translated Text. Cognitive and Communicative Dimensions of the Message", Faculty of Letters, "Dunarea de Jos" University of Galati, Romania.

Conflicts of Interest: The authors declare no conflict of interest.

\section{References}

1. Burada, A.; Topa, C.M.; Georgescu, L.P.; Teodorof, L.; Nastase, C.; Seceleanu-Odor, D.; Iticescu, C. Heavy metals environment accumulation in Somova-Parches aquatic complex from the Danube Delta area. Reveista Chim. 2015, 66, 48-54.

2. Javed, T.; Ahmad, N.; Mashiatullah, A. Heavy metals contamination and ecological risk assessment in surface sediments of Namal Lake, Pakistan. Pol. J. Environ. Stud. 2018, 27, 675-688. [CrossRef]

3. Kumar, R.N.; Solanki, R.; Kumar, J.I.N. Seasonal variation in heavy metal contamination in water and sediments of river sabarmati and Kharicut Canal at Ahmedabad, Gujarat. Environ. Monit. Assess. 2013, 185, 359-368. [CrossRef]

4. Jaishankar, M.; Tseten, T.; Anbalagan, N.; Mathew, B.B.; Beeregowda, K.N. Toxicity, mechanism and health effects of some heavy metals. Interdiscip. Toxicol. 2014, 7, 60-72. [CrossRef]

5. Malassa, H.; Al-Qutob, M.; Al-Khatib, M.; Al-Rimawi, F. Determination of different trace heavy metals in ground water of South West Bank/Palestine by ICP/MS. J. Environ. Prot. Sci. 2013, 4, 720-726. [CrossRef]

6. Faroon, O.; Ashizawa, A.; Wright, S.; Tucker, P.; Jenkins, K.; Ingerman, L.; Rudisill, C. Toxicological Profile for Cadmium; Agency for Toxic Substances and Disease Registry (US): Atlanta, GA, USA, 2012.

7. Buxton, S.; Garman, E.; Heim, K.E.; Lyons-Darden, T.; Schlekat, C.E.; Taylor, M.D.; Oller, A.R. Concise review of nickel human health toxicology and ecotoxicology. Inorganics 2019, 7, 89. [CrossRef]

8. Roney, N.; Osier, M.; Paikoff, S.J.; Smith, C.V.; Williams, M.; De Rosa, C.T. ATSDR evaluation of the health effects of zinc and relevance to public health. Toxicol. Ind. Health 2006, 22, 423-493. [CrossRef]

9. Abadin, H.; Ashizawa, A.; Stevens, Y.-W.; Llados, F.; Diamond, G.; Sage, G.; Citra, M.; Quinones, A.; Bosch, S.J.; Swarts, S.G. Toxicological Profile for Lead; Agency for Toxic Substances and Disease Registry (US): Atlanta, GA, USA, 2007.

10. Taylor, A.A.; Tsuji, J.S.; Garry, M.R.; McArdle, M.E.; Goodfellow, W.L.; Adams, W.J.; Menzie, C.A. Critical review of exposure and effects: Implications for setting regulatory health criteria for ingested copper. Environ. Manag. 2020, 65, 131-159. [CrossRef]

11. Briffa, J.; Sinagra, E.; Blundell, R. Heavy metal pollution in the environment and their toxicological effects on humans. Heliyon 2020, 6, e04691. [CrossRef]

12. Singh, J.; Kalamdhad, A.S. Effects of heavy metals on soil, plants, human health and aquatic life. Int. J. Res. Chem. Environ. 2011, 1, 15-21. 
13. Calmuc, M.; Calmuc, V.; Arseni, M.; Topa, C.; Timofti, M.; Georgescu, L.P.; Iticescu, C. A comparative approach to a series of physico-chemical quality indices used in assessing water quality in the Lower Danube. Water 2020, 12, 3239. [CrossRef]

14. Milenkovic, N.; Damjanovic, M.; Ristic, M. Study of heavy metal pollution in sediments from the Iron Gate (Danube River), Serbia and Montenegro. Pol. J. Environ. Stud. 2005, 14, 781-787.

15. Yaroshenko, I.; Kirsanov, D.; Marjanovic, M.; Lieberzeit, P.A.; Korostynska, O.; Mason, A.; Frau, I.; Legin, A. Real-Time water quality monitoring with chemical sensors. Sensors 2020, 20, 3432. [CrossRef]

16. Sambito, M.; Freni, G. Strategies for improving optimal positioning of quality sensors in urban drainage systems for nonconservative contaminants. Water 2021, 13, 934. [CrossRef]

17. Peyravi, M.; Jahanshahi, M.; Tourani, H. Chapter 6-Analytical methods of water pollutants detection. In Inorganic Pollutants in Water; Devi, P., Singh, P., Kansal, S.K., Eds.; Elsevier: Amsterdam, The Netherlands, 2020; pp. 97-113. ISBN 978-0-12-818965-8.

18. Iticescu, C.; Georgescu, L.P.; Topa, C.; Murariu, G. Monitoring the Danube water quality near the Galati City. J. Environ Prot. Ecol. 2014, 15, 30-38.

19. Iticescu, C.; Georgescu, L.; Maria-Catalina, T. Assessing the Danube water quality index in the city of Galati, Romania. Carpath. J. Earth Environ. Sci. 2013, 8, 155-164.

20. Gasparotti, C. The Main Factors of Water Pollution in Danube River Basin. Euro Econ. 2014, 33, 93-106.

21. Iticescu, C.; Murariu, G.; Georgescu, L.P.; Burada, A.; Topa, M.C. Seasonal variation of the physico-chemical parameters and water quality index (WQI) of Danube Water in the transborder Lower Danube area. Revista Chim. 2016, 67, $1843-1849$.

22. Iordache, M.; Popescu, L.R.; Pascu, L.; Ioan, I. Environmental risk assessment in sediments from Jiu River, Romania. Revista Chim. 2015, 66, 1247-1252.

23. Al Naggar, Y.; Khalil, M.; Ghorab, M. Environmental pollution by heavy metals in the aquatic ecosystems of Egypt. Open Acess J. Toxicol. 2018, 3. [CrossRef]

24. Iticescu, C.; Georgescu, L.; Murariu, G.; Maria-Catalina, T.; Mihaela, T.; Pintilie, V.; Arseni, M. Lower Danube water quality quantified through WQI and multivariate analysis. Water 2019, 11, 1305. [CrossRef]

25. Demirak, A.; Yilmaz, F.; Tuna, A.L.; Ozdemir, N. Heavy metals in water, sediment and tissues of leuciscus cephalus from a stream in southwestern Turkey. Chemosphere 2006, 63, 1451-1458. [CrossRef]

26. Takarina, N.D.; Adiwibowo, A. Impact of heavy metals contamination on the biodiversity of marine benthic organisms in Jakarta Bay. J. Coast. Zone Manag. 2011, 14, 168-171.

27. Muller, G. Index of geoaccumulation in sediments of the Rhine River. Geojournal 1969, 2, 108-118.

28. Zhiyuan, W.; Dengfeng, W.; Huiping, Z.; Zhiping, Q. Assessment of soil heavy metal pollution with principal component analysis and geoaccumulation index. Procedia Environ. Sci. 2011, 10, 1946-1952. [CrossRef]

29. Fan, Z.; Wang, W.; Tang, C.; Li, Y.; Wang, Z.; Lin, S.; Zeng, F. Targeting remediation dredging by ecological risk assessment of heavy metals in lake sediment: A Case Study of Shitang Lake, China. Sustainability 2019, 11, 7251. [CrossRef]

30. Literáthy, P.; László, F. Micropollutants in the Danube River basin. Water Sci. Technol. 1999, 40, 17-26. [CrossRef]

31. Woitke, P.; Wellmitz, J.; Helm, D.; Kube, P.; Lepom, P.; Litheraty, P. Analysis and assessment of heavy metal pollution in suspended solids and sediments of the River Danube. Chemosphere 2003, 51, 633-642. [CrossRef]

32. Ilie, M.; Marinescu, F.; Robert, S.; Ghita, G.; Deak, G.; Anghel, A.-M.; Petrescu, A.; Uritescu, B. Ecological risk assessment of heavy metals in surface sediments from the Danube River. Carpath. J. Earth Environ. Sci. 2017, 12, 437-445.

33. Hounkpè, J.B.; Kèlomè, N.; Adèchina, R.; Rébecca, L. Assessment of heavy metals contamination in sediments at the Lake of Ahémé in southern of Benin (west Africa). J. Mater. Environ. Sci. 2017, 8, 4369-4377. [CrossRef]

34. Cevik, F.; Göksu, M.Z.L.; Derici, O.B.; Findik, O. An assessment of metal pollution in surface sediments of Seyhan Dam by using enrichment factor, geoaccumulation index and statistical Analyses. Environ. Monit. Assess. 2009, 152, 309-317. [CrossRef]

35. Ali, A.-E.; Strezov, V.; Davies, P.J.; Wright, I. River Sediment Quality Assessment Using Sediment Quality Indices for the Sydney Basin, Australia Affected by Coal and Coal Seam Gas Mining. Sci. Total Environ. 2018, 616-617, 695-702. [CrossRef]

36. Huang, Z.; Liu, C.; Zhao, X.; Dong, J.; Zheng, B. Risk Assessment of heavy metals in the surface sediment at the drinking water source of the Xiangjiang River in South China. Environ. Sci. Eur. 2020, 32, 23. [CrossRef]

37. Zhang, W.; Long, J.; Zhang, X.; Shen, W.; Wei, Z. Pollution and ecological risk evaluation of heavy metals in the soil and sediment around the HTM tailings pond, Northeastern China. Int. J. Environ. Res. Publ. Health 2020, 17, 7072. [CrossRef]

38. Li, X.; Shen, H.; Zhao, Y.; Cao, W.; Hu, C.; Sun, C. Distribution and potential ecological risk of heavy metals in water, sediments, and aquatic macrophytes: A case study of the junction of four rivers in Linyi City, China. Int. J. Environ. Res. Publ. Health 2019, 16, 2861. [CrossRef] [PubMed]

39. Ouchir, N.; Aissa, L.B.; Boughdiri, M.; Aydi, A. Assessment of heavy metal contamination status in sediments and identification of pollution source in Ichkeul Lake and rivers ecosystem, northern Tunisia. Arab. J. Geosci. 2016, 9, 1-12. [CrossRef]

40. Chandrasekaran, A.; Mukesh, M.V.; Chidambaram, S.; Singarasubramanian, S.R.; Rajendran, S.; Muthukumarasamy, R.; Tamilselvi, M. Assessment of heavy metal distribution pattern in the sediments of Tamirabarani River and estuary, east coast of Tamil Nadu, India. Environ. Earth Sci. 2014, 73, 2441-2452. [CrossRef]

41. Patel, P.; Raju, N.J.; Reddy, B.C.S.R.; Suresh, U.; Sankar, D.B.; Reddy, T.V.K. Heavy metal contamination in river water and sediments of the Swarnamukhi River Basin, India: Risk assessment and environmental implications. Environ. Geochem. Health 2018, 40, 609-623. [CrossRef] 
42. Jahan, S.; Strezov, V. Comparison of pollution indices for the assessment of heavy metals in the sediments of seaports of NSW, Australia. Mar. Polut. Bull. 2018, 128, 295-306. [CrossRef]

43. Ganugapenta, S.; Nadimikeri, J.; Chinnapolla, B.R.R.S.; Lakshmanna, B.; Madiga, R.; Nirmala, K.; Tella, L. Assessment of heavy metal pollution from the sediment of Tupilipalem Coast, southeast coast of India. Int. J. Sediment Res. 2018, 33, 294-302. [CrossRef]

44. Zhou, Z.; Wang, Y.; Teng, H.; Yang, H.; Liu, A.; Li, M.; Niu, X. Historical evolution of sources and pollution levels of heavy metals in the sediment of the Shuanglong Reservoir, China. Water 2020, 12, 1855. [CrossRef]

45. Hakanson, L. An ecological risk index for aquatic pollution control.a sedimentological approach. Water Res. 1980, 14, 975-1001. [CrossRef]

46. Xu, J.; Chen, Y.; Zheng, L.; Liu, B.; Liu, J.; Wang, X. Assessment of heavy metal pollution in the sediment of the main tributaries of Dongting Lake, China. Water 2018, 10, 1060. [CrossRef]

47. Romanian Ministry of Research and Innovation. Order 161/2006, the normative on the classification of surface water quality in order to establish the ecological Romanian ministry of research and innovation. In Status of Water Bodies; Official Monitor: Bucharest, Romania, 2006.

48. Wu, B.; Wang, G.; Wu, J.; Fu, Q.; Liu, C. Sources of heavy metals in surface sediments and an ecological risk assessment from two adjacent plateau reservoirs. PLoS ONE 2014, 9, e102101. [CrossRef]

49. Teodorof, L.; Burada, A.; Despina, C.; Seceleanu-Odor, D.; Tudor, A.; Ibram, O.; Navodaru, I.; Tudor, M. Integrated indices for surface water and sediment quality, according to water framework directive. J. Environ. Prot. Ecol. 2016, 17, 42-52.

50. Chen, M.; Li, F.; Tao, M.; Hu, L.; Shi, Y.; Liu, Y. Distribution and Ecological Risks of Heavy metals in river sediments and overlying water in typical mining areas of China. Mar. Polut. Bull. 2019, 146, 893-899. [CrossRef]

51. Xiao, H.; Shahab, A.; Li, J.; Xi, B.; Sun, X.; He, H.; Yu, G. Distribution, ecological risk assessment and source identification of heavy metals in surface sediments of Huixian Karst Wetland, China. Ecotoxicol. Environ. Saf. 2019, 185, 109700. [CrossRef]

52. Cui, S.; Zhang, F.; Hu, P.; Hough, R.; Fu, Q.; Zhang, Z.; An, L.; Li, Y.-F.; Li, K.; Liu, D.; et al. Heavy metals in Sediment from the Urban and Rural Rivers in Harbin City, Northeast China. Int. J. Environ. Res. Pub. Health 2019, 16, 4313. [CrossRef]

53. Wan, L.; Xu, L.; Fu, Y. Contamination and risk assessment of heavy metals in lake bed sediment of a large lake scenic area in China. Int. J. Environ. Res. Pub. Health 2016, 13, 741. [CrossRef]

54. Liu, P.; Zheng, C.; Wen, M.; Luo, X.; Wu, Z.; Liu, Y.; Chai, S.; Huang, L. Ecological risk assessment and contamination history of heavy metals in the sediments of Chagan Lake, northeast China. Water 2021, 13, 894. [CrossRef]

55. Mar, S.S.; Okazaki, M. Investigation of cd contents in several phosphate rocks used for the production of fertilizer. Microchem. J. 2012, 104, 17-21. [CrossRef]

56. Wu, Q.; Qi, J.; Xia, X. Long-Term Variations in sediment heavy metals of a reservoir with Changing Trophic States: Implications for the Impact of Climate Change. Sci. Total Environ. 2017, 609, 242-250. [CrossRef]

57. Simionov, I.-A.; Cristea, D.S.; Petrea, S.-M.; Mogodan, A.; Nicoara, M.; Plavan, G.; Baltag, E.S.; Jijie, R.; Strungaru, S.-A. Preliminary investigation of Lower Danube pollution caused by potentially toxic metals. Chemosphere 2021, 264, 128496. [CrossRef]

58. Harasim, P.; Filipek, T. Nickel in the environment. J. Elementol. 2015, 20, 525-534. [CrossRef]

59. Arseni, M.; Rosu, A.; Calmuc, M.; Calmuc, V.A.; Iticescu, C.; Georgescu, L.P. Development of flood risk and hazard maps for the lower course of the Siret River, Romania. Sustainability 2020, 12, 6588. [CrossRef]

60. Arseni, M.; Voiculescu, M.; Georgescu, L.P.; Iticescu, C.; Rosu, A. Testing different interpolation methods based on single beam echosounder river surveying. case Study: Siret River. ISPRS Int. J. Geo Inf. 2019, 8, 507. [CrossRef]

61. Navarrete-Rodríguez, G.; Castañedaz-Chávez, M.d.R.; Lango-Reynoso, F. Geoacumulation of heavy metals in sediment of the fluvial-lagoon-deltaic system of the Palizada River, Campeche, Mexico. Int. J. Environ. Res. Pub. Health 2020, 17, 969. [CrossRef] 